\title{
PRIMARY SMALL CELL CARCINOMA OF LUNG WITH METACHRONOUS BREAST METASTASIS
}

\author{
Marina Markovic ${ }^{1}$, Dalibor Jovanovic ${ }^{2}$, Zeljko Todorovic ${ }^{1}$, Marija Zivkovic ${ }^{3}$, Aleksandar Dagovic ${ }^{4}$, \\ Slobodanka Mitrović ${ }^{2}$, Marina Petrovići ${ }^{1}$ Jelena Nešić ${ }^{1}$ \\ ${ }^{1}$ University of Kragujevac, Serbia, Faculty of Medical Sciences, Department of Internal medicine \\ ${ }^{2}$ University of Kragujevac, Serbia, Faculty of Medical Sciences, Department of Pathology \\ ${ }^{3}$ Center of Oncology, Clinical Center "Kragujevac", Serbia \\ ${ }^{4}$ University of Kragujevac, Serbia, Faculty of Medical Sciences, Department of Clinical oncology \\ PRIMARNI MIKROCELULARNI KARCINOM PLUĆA \\ SA METAHRONOM METASTAZOM U DOJCI

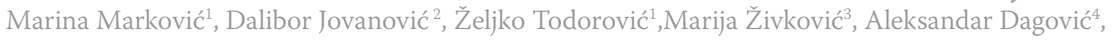 \\ Slobodanka Mitrović ${ }^{2}$, Marina Petrovići ${ }^{\text {, Jelena Nešić }}{ }^{1}$ \\ ${ }^{1}$ Katedra za internu medicinu, Fakultet medicinskih nauka, Univerzitet u Kragujevcu, Srbija \\ ${ }^{2}$ Katedra za patološku anatomiju, Fakultet medicinskih nauka, Univerzitet u Kragujevcu, Srbija \\ ${ }^{3}$ Centar za Onkologiju, Klinički Centar "Kragujevac", Serbia \\ ${ }^{4}$ Katedra za kliničku onkologiju, Fakultet medicinskih nauka, Univerzitet u Kragujevcu, Srbija
}

Received / Primljen: 13. 07. 2016

Accepted / Prihvaćen: 07. 11. 2016.

\begin{abstract}
Breast metastases from an extra-mammary malignancy are rare. Among the lung malignancies that metastasise in the breasts, previous literature has described approximately 30 cases of NSCLC and only a few cases of SCLC. Here, we present a 54-year-old woman with metachronous breast metastasis from pulmonary small cell carcinoma. She presented with a soft tissue mass in the right lung hilum. After bronchoscopy with biopsy, SCLC was verified. The patient was given 4 cycles of etoposide and cisplatin followed by radiation therapy. Seven months after the diagnosis of primary lung cancer, the patient palpated a mass in her right breast. Clinical examination and further diagnostics revealed the suspected malignancy, and a radical mastectomy was performed. Immunohistochemical findings suggested metastatic SCLC in the breast. Differentiation between primary and metastatic cancer in the breast is very important for therapeutic planning.
\end{abstract}

Keywords: small cell lung carcinoma, metachronous metastasis, breast carcinoma

\section{SAŽETAK}

Dojka predstavlja retko mesto ekstramamarnih metastaza. Među karcinomima pluća koji su prezentovani sa metastazom u dojci, u literaturi je opisano oko 30 slučajeva NSCLC $i$ samo nekoliko slučajeva SCLC. Mi smo prikazali pacijentkinju starosti 54 godine sa metahronom metastazom sitnoćelijskog carcinoma pluća u dojku. Pacijentkinji je inicijalno dijagnostikovana mekotkivna masa u desnom hilusu pluća. Nakon bronhoskopije $i$ biopsije tumourskog tkiva, postavljena je dijagnoza sitnoćelijskog karcinoma pluća. Pacijentkinja je lečena sa 4 ciklusa hemioterapije po protokolu etopozid i cisplatina, nakon čega je nastavljena radioterapija. Sedam meseci nakon postavljanja dijagnoze primarnog carcinoma pluća, pacijentkinja je napipala čvor u desnoj dojci. Klinički pregled i dodatna dijagnostika su pokazali da se najverovatnije radi o malignom tumouru. Uradena je radikalna mestektomija. Imunohistohemijska analiza je ukazala na metastazu sitnoćelijskog karcinoma u dojku. Diferencijalna dijagnoza izmedu primarnog $i$ metastatskog karcionoma dojke je veoma bitna radi daljeg planiranja terapije.

Ključne reči: sitnoćelijski karcinom pluća, metahrone metastaze, karcinom dojke

\section{ABBREVIATIONS}

SCLC: small cell lung carcinoma

NSCLC: non-small cell lung carcinoma

LD: limited disease

\section{INTRODUCTION}

Small cell lung cancer (SCLC) is an aggressive malignancy that comprises $13-15 \%$ of all lung cancers (1). At the time of diagnosis, SCLC presents itself as a metastatic disease in $60 \%$ of cases. The most common places for metastasis are the liver (35\%), brain ( $47 \%)$, bones (25\%), adrenal gland (8\%) and lungs (12\%) (2). Metastasis in the breasts

represents an extremely rare phenomenon, and it occurs in $0,4-1,3 \%$ of cases (3). Primary malignancies that usually metastasise in the breasts are melanoma $(29,8 \%)$, lung carcinoma $(16,4 \%)$, ovarian and endometrial cancer $(12,7 \%)$, intestinal carcinoma $(9,9 \%)$, leukaemia and lymphoma $(8,4 \%)$, rhabdomyosarcoma $(7,3 \%)$ and renal cell carci- 


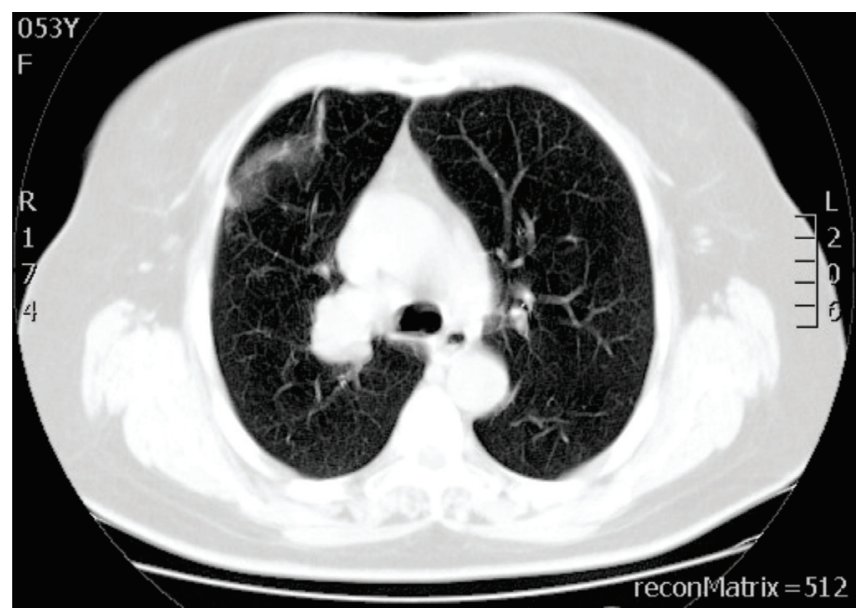

Figure 1. CT scan of the thorax shows a soft tissue mass in the right lung hilum with dimensions of $24 \times 30 \mathrm{~mm}$.

noma (1,5\%) (4). Among lung cancers that metastasise in the breasts, the literature has described approximately 30 cases of NSCLC and only a few cases of SCLC (5-9). Here, we report the case of a 54-year-old woman with breast metastasis from SCLC.

\section{CASE REPORT}

A 54-year-old woman who smoked 20 cigarettes a day for 40 years presented with dyspnoea, orthopnoea, exhaus-
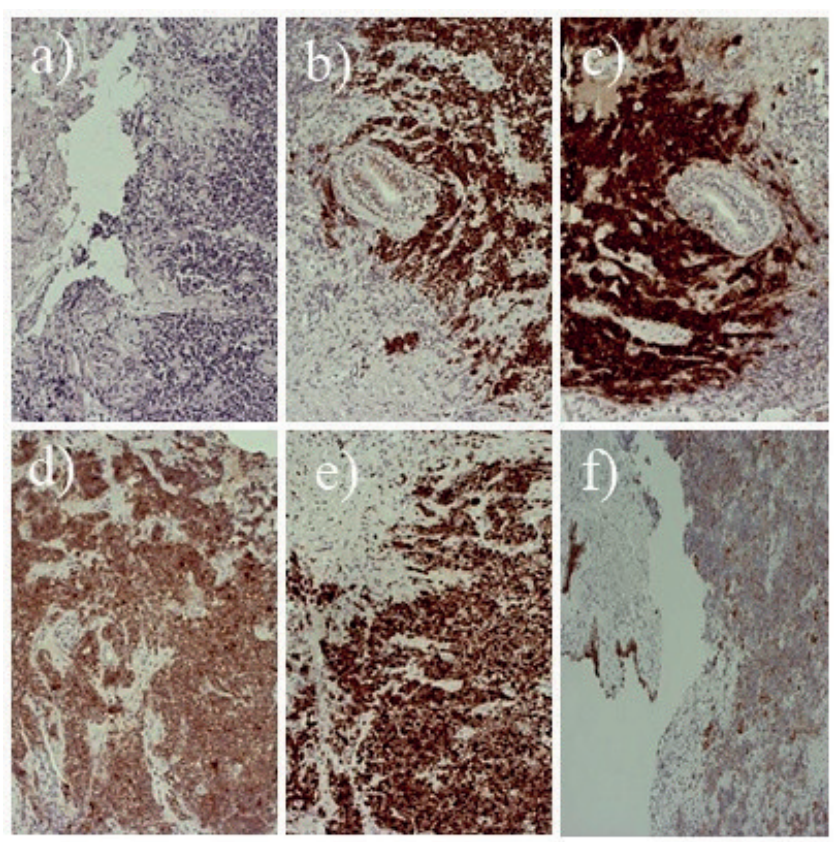

Figure 2. Primary small cell carcinoma of the lung: a) haematoxylin and eosin staining shows fragments of bronchial mucosa imbued with irregular tumour sheets and ribbon tumour arrangements consisting of easy polymorphic cells, about twice the size of lymphocytes with scant cytoplasm and large hyperchromatic nuclei. Immunohistochemical tumour cells were diffusely positive for b) TTF-1, c) CD56, and d) chromogranin. e) The proliferation index was high; around $90 \%$ of the tumour cell nuclei are expressing Ki67. f) CK7 was partially positive. tion, coughing and subfebrile temperature (up to $37,5^{\circ} \mathrm{C}$ ). She had been experiencing these ailments for two months. A computed tomography (CT) scan of the thorax showed a soft tissue mass in the right lung hilum with dimensions of $24 \times 30 \mathrm{~mm}$, without mediastinal lymphadenopathy and without contents in the pleural spaces (Figure 1). The liver, spleen, adrenal glands and other abdominal organs did not exhibit morphological changes. After bronchoscopy with biopsy, SCLC was verified (Figure 2). As the tumour mass was only on one side of the chest and can be treated with a single radiation field, it was staged as limited disease (LD). The patient was given 4 cycles of etoposide and cisplatin followed by radiation therapy.

Seven months after the diagnosis of the primary lung cancer, the patient palpated a mass in her right breast. Clinical examination revealed a change in the lower lateral quadrant of the right breast, approximately $40 \mathrm{~mm}$ in size, that was hard, painless and had a fixed base. Breast ultrasound revealed a heterogeneous, lobulated mass that was consistent with malignancy. Considering that the ex tempore biopsy showed a malignancy with the impression of primary breast carcinoma, a radical mastectomy was performed. The tumour cells were positive for CD56, chromogranin, synaptophysin, and neuron-specific enolase (NSE) and did not express receptors for oestrogen (ER), progesterone (PR) or human epidermal growth factor receptor 2 (HER-2). The cells were diffusely positive for thyroid transcription factor-1 (TTF-1) and p53 and focally positive for EMA, cytokeratin 7 (CK7) and CK8, while they were negative for mammaglobin, gross cystic disease fluid protein 15 (GCDFP-15), CK5/6, CK14, CK20, BerEP4, vimentin and p63; the cells also revealed a high proliferation index (Ki67 $90 \%)$. No evidence of in situ carcinoma was observed. The histomorphological image together with the obtained immunophenotype of the cancer cells corresponded to small cell cancer metastasis, which was primarily localised in the lungs (Figure 3).

Due to postural instability and headaches, another cranial CT examination was performed one month after the operation. The results of CT demonstrated metastatic changes. Palliative radiotherapy was administered at a dosage 25 Gy in 5 fractions. Because of the poor general health of the patient, further treatment was continued with symptomatic and supportive therapy. The patient died 15 months after the diagnosis of primary lung cancer and three months after the diagnosis of breast metastasis.

\section{DISCUSSION}

In rare cases, the breasts could be a location for metastasis from the contralateral side, while extra-mammary primary neoplasm metastases are exceptionally rare. The reason for this metastasis can be a large surface of fibrous tissue in the breast and a relatively poor blood supply (10). Mirrielees et al. published a systematic review of the literature on breast metastasis from primary lung carci- 


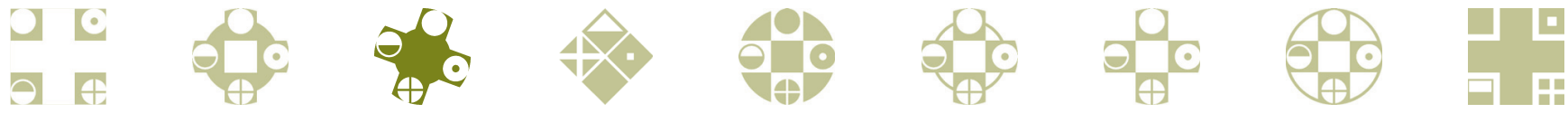
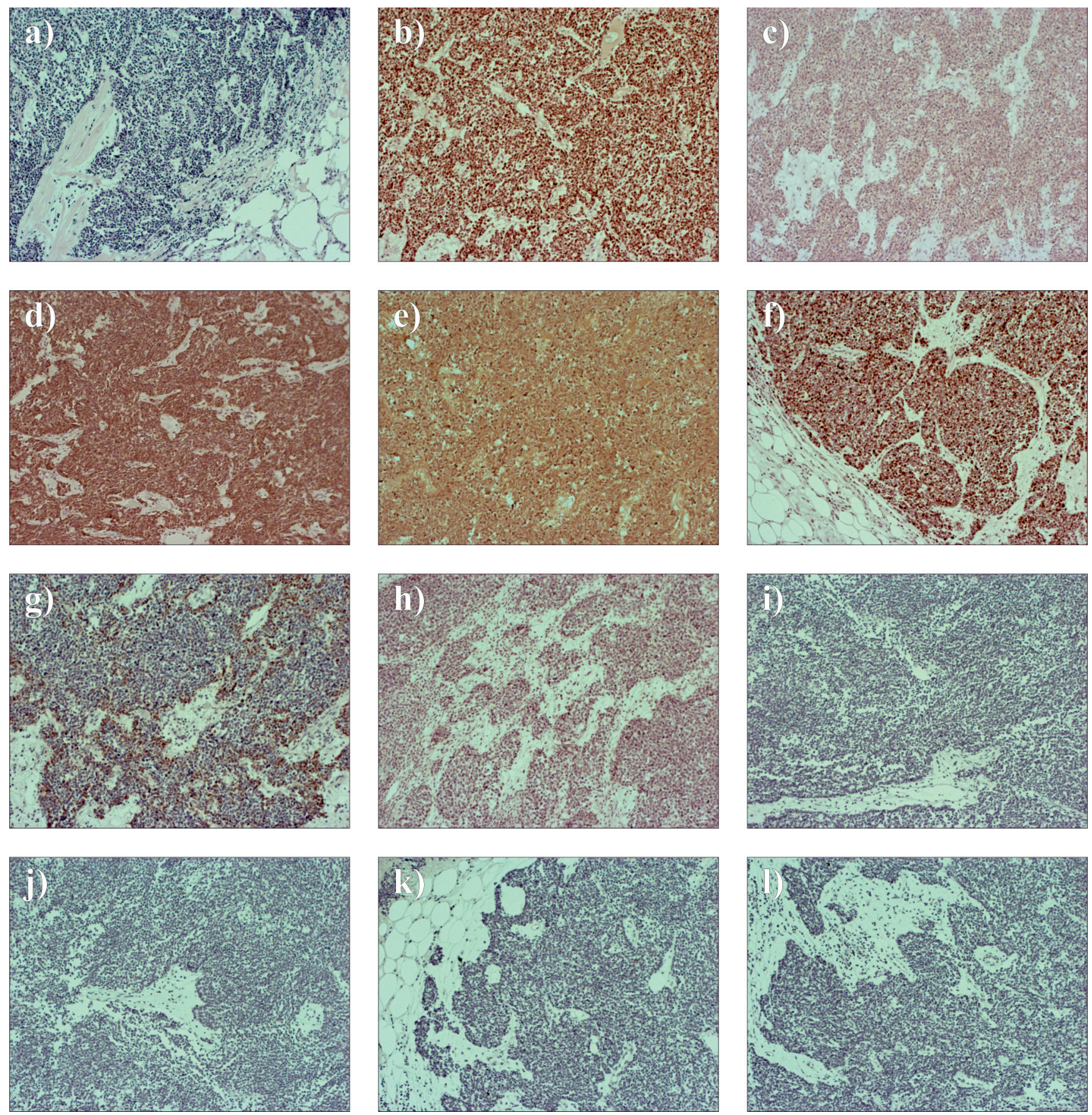

Figure 3. Metastases of small cell lung cancer in the breast: a) haematoxylin and eosin staining of the metastatic breast tumour showed irregular tumour sheets consisting of easy polymorphic cells, about twice the size of lymphocytes with scant cytoplasm and large hyperchromatic nuclei. Immunohistochemical tumour cells were positive for b) TTF-1, c) synaptophysin, d) CK8, and e) NSE. f) The proliferation index was high; around 90\% of the tumour cell nuclei are expressing Ki67. g) CK7 was partially positive, while other markers were negative, including h) CK5/6, i) mammaglobin, j) ER, k) PR, and l) HER2.

noma. Thirty-one cases of non-small cell lung carcinoma (NSCLC) were identified with metastases in the breasts, and eight cases of SCLC were identified with metastases in the breasts. Sixty-seven percent of the presented breast metastases of NSCLC patients were metachronous, while in $80 \%$ of the primary SCLC cases, breast metastases were synchronous (11).

The influence of oestrogen was indicated as a risk factor for the appearance of breast metastasis, especially in younger women, which increases vascularisation and loosens the breast stoma. In the literature, breast metastases were described in men who were treated with oestrogen hormonal therapy due to primary prostate carcinoma (12).

Metastasis to the breast occurs either by direct invasion, pleural seeding, haematogenous dissemination or lymphatic spreading. With lymphatic spreading, there is an assumption that the lung cancer cells first metastasise to the ipsilateral axillar lymph nodules, then retrogradely 
spread to the intra-mammary lymphatic system, and finally establish breast metastasis (13). Clinically, a breast metastasis is presented as a palpable, quickly growing, well-limited, painless tumour mass whose preferred location is the upper outer quadrant of the breast. Retraction of the skin above the affected part of the breast or the nipple is not a characteristic of the metastasis. A mammogram shows the breast metastasis as a limited mass, while irregular edges, spiculations and micro-classifications are rarely observed. Breast metastases are localised in subcutaneous tissue unlike primary carcinoma, which develops in the breast glandular parenchyma.

Differential diagnosis between primary and secondary breast carcinoma often presents a challenge, especially in the case of poorly differentiated tumours. Histological detection of an in situ intra-ductal component is of great importance because supports primary breast carcinoma. Metastatic deposits are sharply limited compared to surrounding breast tissue. Elastosis and calcification are characteristics of primary breast carcinoma but rarely of metastases. SCLC cells express neuroendocrine differentiation markers, usually CD56, synaptophysin, NSE or chromogranin. TTF-1 has a role in the regulation of protein expression in the thyroid gland, lungs and diencephalon, and as such represents a specific and sensitive marker for diagnosis of lung adenocarcinoma (14).

TTF-1 was positive in 93\% of SCLCs and negative in breast adenocarcinomas $(15,16)$. According to the literature, $2,8 \%$ of primary breast carcinomas can show weak or focal expression of TTF-1, and those cases are usually associated with CK5/6 or P-cadherin positivity, grade 3 tumours and the 'triple negative' (ER-, PR- and HER2-negative) phenotype. Napsin $A$ is a sensitive marker for lung adenocarcinoma, which is why the combination of Napsin A and TTF-1 is better for establishing or excluding metastasis in the primary lung carcinoma of the breast compared to using only TTF-1 $(17,18)$.

The 8 G7G3/1 clone of TTF-1 is less sensitive but more specific with regard to SPT24, which is why it is recommended for routine use in order to avoid doubts when determining an adequate diagnosis.

Markers that are in favour of primary breast cancer are receptors for ER, PR, GCDFP-15 and mammoglobin. Receptors for ER are expressed in $80 \%$ and GCDFP-15 in $45-53 \%$ of primary breast carcinomas. Expression of ER in lung carcinoma is low $(7,6-14,1 \%)$ as well as expression of GCDFP-15 (5,2-15\%). Mammoglobin is expressed in 48$72,1 \%$ of breast carcinomas and is negative in lung carcinomas (19-22).

The combination of CK7 and CK20 is irreplaceable in a crude differentiation with regard to the origin of cancer. Breast carcinomas are mostly CK7+ and CK20-, while it is less probable that the malignancy is a breast carcinoma if it is CK20+ and CK7- (23).

Breast metastases from non-breast solid malignancies are associated with a poor outcome; the median survival from the time of breast metastasis diagnosis is 10 months. Significantly better survival was observed in patients who had no evidence of another disease at the time of diagnosis, in patients with neuroendocrine tumours, and in patients who underwent surgical resection for breast metastases (24).

Surgical treatment of the metastatic change in a breast represents an option for the treatment of metachronous metastases, although it is not completely clear if surgical treatment may influence the prognosis of the disease. For patients presenting synchronous lung cancer with breast metastasis, removal of the breast lesion offers no benefit to the patient (11).

In our case, we presented a patient with breast cancer in the T2-N0 clinical stage. Cancer metastases in the breast are extremely rare, and taking into account the high prevalence of primary breast cancer, a palpable tumour mass was considered a new primary breast tumour. Fine-needle aspiration (FNA) cytology and needle core biopsies with immunohistochemical analyses should be the diagnostic procedures of choice in patients with a palpable tumour mass in the breast, especially in those with a previously diagnosed malignant disease, in order to avoid unnecessary radical surgery. If the axillary lymph nodes are not palpable, axillary imaging with ultrasound should be considered, and suspicious nodes should be sampled by FNA or core biopsy. Neoadjuvant chemotherapy with possible surgical resection is a therapeutic option in those patients without distant metastases.

\section{CONCLUSION}

Breast metastases from SCLC represent an extremely rare phenomenon. These metastases mainly occur in the contralateral breast, while in only $0,5 \%$ of cases, the metastases result from extra-mammary primary tumours. Since the treatment and prognosis of the diseases are different, it is important that the differentiation be made between primary and metastatic breast carcinoma. Information about previously diagnosed malignancies is of great importance, especially regarding metachronous metastases, in order to carry out the necessary diagnostic procedures so that the most adequate therapeutic modality can be provided to the patient.

\section{REFERENCES}

1. Alvarado-Luna G, Morales-Espinosa D. Treatment for small cell lung cancer, where are we now?-a review. Transl Lung Cancer Res 2016;5(1):26-38

2. Nakazawa K, Kurishima K, Tamura T, Kagohashi K, Ishikawa $\mathrm{H}$, Satoh $\mathrm{H}$, et al. Specific organ metastases and survival in small cell lung cancer. Oncol Lett. 2012;4:617-620

3. Ji FF, Gao P, Wang JG, Zhao J, Zhao P. Contralateral breast metastasis from pulmonary adenocarcinoma: two cases report and literature review. J Thorac Dis. 2012;4:384-389 
4. Koch A, Richter-Marot A, Wissler MP, Baratte A and Mathelin C. [Mammary metastasis of extramammary cancers: current knowledge and diagnostic difficulties]. Gynecol Obstet Fertil 2013;41:653-659.

5. Liu W, Palma-Diaz F, Alasio TM. Primary small cell carcinoma of the lung initially presenting as a breast mass: a fine-needle aspiration diagnosis. Diagn Cytopathol. 2009; 37: 208-212.

6. Jakovljević B, Stevanović O, Bacić G. Metastases to the breast from small-cell lung cancer: MR findings. A case report. Acta Radiol. 2003;44:485-488.

7. Luh S, Kuo C, Tsao TC. Breast metastasis from small cell lung carcinoma. Journal of Zhejiang University Science B. 2008;9(1):39-43. doi:10.1631/jzus.B072258.

8. Assi HA, Khoury KE, Mouhieddine TH, Khalil LE, Kanj A, et al. Small Cell Lung Cancer with Metastasis to the Breast: A Case Report and Review of the Literature. J Cancer Biol Res.2014; 2(1):1025

9. Altintoprak F, Baytekin HF, Tasdemir C. Primary Small Cell Carcinoma of the Lung Presenting with Breast and Skin Metastases. The Korean Journal of Internal Medicine. 2011;26(2):207-209. doi:10.3904/ kjim.2011.26.2.207.

10. Mun SH, Ko EY, Han BK, Shin JH, Kim SJ, Cho EY. Breast metastases from extramammary malignancies: typical and atypical ultrasound features. Korean J Radiol 2014;15(1):20-8.

11. Mirrielees JA, Kapur JH, Szalkucki LM, Harter JM, Salkowski LR, Strigel RM, Traynor AM, Wilke LG: Metastasis of primary lung carcinoma to the breast: a systematic review of the literature. J Surg Res. 2014;188: 419-431. 10.1016/j.jss.2014.01.024.

12. Seung Hee Lee, MD, Jeong Mi Park, MD, Shin Ho Kook, MD et al. Metastatic Tumors to the Breast: Mammographic and Ultrasonographic Findings.J Ultrasound Med. 2000 Apr;19(4):257-62.

13. Huang, Hsu-Ching et al. Lung Adenocarcinoma with Ipsilateral Breast Metastasis: A Simple Coincidence? Journal of Thoracic Oncology 2013; Volume 8, Issue7, 974 - 979
14. Ordonez NG. Value of thyroid transcription factor-1 immunostaining in tumor diagnosis: a review and update. Appl Immunohistochem Mol Morphol 2012;20:429-44.

15. FF, Gao P, Wang JG, Zhao J, Zhao P. Contralateral breast metastasis from pulmonary adenocarcinoma: two cases report and literature review. J Thorac Dis. 2012; 4: 384-389.

16. Sanguinetti A, Puma F, Lucchini R, Santoprete S, Cirocchi $\mathrm{R}$, Corsi A, et al. Breast metastasis from a pulmonary adenocarcinoma: Case report and review of the literature. Oncol Lett. 2013;5: 328-332.

17. Robens J, Goldstein L, Gown AM, et al. Thyroid transcription factor-1 expression in breast carcinomas. Am J Surg Pathol. 2010;34:1881-5.

18. Klingen TA, Chen Y, Suhrke P, et al. Expression of thyroid transcription factor-1 is associated with a basal-like phenotype in breast carcinomas. Diagnostic Pathology 2013;8:80.

19. Takeda Y, Tsuta K, Shibuki Y, Hoshino T, Tochigi N, Maeshima AM, Asamura H, Sasajima Y, Ito T, Matsuno Y: Analysis of expression patterns of breast cancerspecific markers (mammaglobin and gross cystic disease fluid protein 15) in lung and pleural tumors. Arch Pathol Lab Med. 2008;132:239-243.

20. Yang M, Nonaka D: A stydy of immunohistochemical differential expression in pulmonary and mammary carcinomas. Mod Pathol. 2010;23:654-661.

21. Striebel JM, Dacic S, Yousem SA: Gross cystic disease fluid protein-(GCDFP-15): expression in primary lung adenocarcinoma. Am J Surg Pathol 2008;32:426-432.

22. Bhargava R, Beriwal S, Dabbs DJ: Mammaglobin vs GCDFP-15: animmunohistologic validation survey for sensitivity and specificity. Am JClin Pathol 2007;127:103-113

23. Tot T: Cytokeratin 20 and 7 as biomarkers: usefulness in discriminating primary from metastatic adenocarcinoma. Eur J Cancer. 2002;38: 758-763. 10.1016/S09598049(02)00008-4.

24. Williams S A, Ehlers R A 2nd, Hunt K K. et al. Metastases to the breast from nonbreast solid neoplasms: presentation and determinants of survival. Cancer. 2007;110:731-737 